\title{
Ultrasound-Assisted Extraction and Identification of Natural Antioxidants from the Fruit of Melastoma sanguineum Sims
}

\author{
Tong Zhou ${ }^{1}$, Dong-Ping Xu ${ }^{1}$, Sheng-Jun Lin ${ }^{2}$, Ya Li ${ }^{1}$, Jie Zheng ${ }^{1}$, Yue Zhou ${ }^{1}$, Jiao-Jiao Zhang ${ }^{1}$ \\ and Hua-Bin $\mathrm{Li}^{1,3, *}$ \\ 1 Guangdong Provincial Key Laboratory of Food, Nutrition and Health, School of Public Health, \\ Sun Yat-Sen University, Guangzhou 510080, China; zhout43@mail2.sysu.edu.cn (T.Z.); \\ xudp@mail2.sysu.edu.cn (D.-P.X.); liya28@mail2.sysu.edu.cn (Y.L.); zhengj37@mail2.sysu.edu.cn (J.Z.); \\ zhouyue3@mail2.sysu.edu.cn (Y.Z.); zhangij46@mail2.sysu.edu.cn (J.-J.Z.) \\ 2 Zhongshan Center for Disease Control and Prevention, Zhongshan 528403, China; zscdclsj@163.com \\ 3 South China Sea Bioresource Exploitation and Utilization Collaborative Innovation Center, \\ Sun Yat-Sen University, Guangzhou 510006, China \\ * Correspondence: lihuabin@mail.sysu.edu.cn; Tel.: +86-20-8733-2391
}

Academic Editor: Gregory Chatel

Received: 13 January 2017; Accepted: 15 February 2017; Published: 18 February 2017

\begin{abstract}
The fruit of Melastoma sanguineum Sims is an edible and sweet wild fruit. In our previous study, the fruit was found to have a strong antioxidant property. In this study, an ultrasound-assisted extraction (UAE) method was developed to extract natural antioxidants from the fruit of Melastoma sanguineum Sims, and a response surface methodology was used to optimize the conditions of UAE to maximize the extraction efficiency. The influence of five independent extraction parameters (ethanol concentration, solvent/material ratio, extracting time, temperature, and ultrasound power) on the extraction efficiency were investigated using a single factor experiment, and then a central composite rotatable design was used to investigate the interaction of three key parameters. The results showed that the optimal extraction conditions were $42.98 \%$ ethanol, $28.29 \mathrm{~mL} / \mathrm{g}$ solvent/material ratio, $34.29 \mathrm{~min}$ extracting time, $60^{\circ} \mathrm{C}$ temperature, and $600 \mathrm{~W}$ ultrasound power. Under these conditions, the Trolox equivalent antioxidant capacity (TEAC) value of the extracts was $1074.61 \pm 32.56 \mu \mathrm{mol}$ Trolox/g dry weight (DW). Compared with conventional maceration $(723.27 \pm 11.61 \mu \mathrm{mol}$ Trolox/g DW) and Soxhlet extraction methods (518.37 $\pm 23.23 \mu \mathrm{mol}$ Trolox/g DW), the UAE method improved the extraction efficiency, in a shorter period of time. In addition, epicatechin gallate, epicatechin, rutin, epigallocatechin, protocatechuic acid, chlorogenic acid, and quercetin, were identified and quantified in the fruit extracts of Melastoma sanguineum Sims by UPLC-MS/MS.
\end{abstract}

Keywords: Melastoma sanguineum Sims; fruit; antioxidant; ultrasound-assisted extraction; response surface methodology; phenolic compounds

\section{Introduction}

Free radicals include reactive oxygen species (ROS), reactive sulfur species (RSS), and reactive nitrogen species (RNS) [1]. They are generated as a part of normal cellular metabolism. However, many external factors (smoking, drugs, pesticides, environmental pollutants, radiation, and industrial solvents) can increase the production of free radicals [2]. The overproduction of free radicals can result in oxidative stress, which is involved in many chronic and degenerative diseases, such as atherosclerosis, coronary heart diseases, diabetes mellitus, neurodegenerative diseases, ageing, 
and cancer [3-5]. Several epidemiological studies have verified that a high intake of vegetables and fruits are related with a reduced risk of many chronic diseases, such as hypertension, coronary heart disease, and cancer [6,7]. These health benefits might be attributable to the presence of antioxidants in vegetables and fruits. The antioxidants from plant sources are able to scavenge excess free radicals, inhibit lipid oxidation, and reduce the hydroperoxide formation, which could protect an organism against oxidative stress [8]. Some antioxidants from plant sources have been proved to have anti-aging actions, anticancer actions, and protective actions against cardiovascular diseases, obesity, diabetes mellitus, and neurodegenerative diseases [9]. Therefore, the antioxidants from plant sources can be used as potential agents for preventing and treating oxidative stress-related diseases [10]. In addition, natural antioxidants can be used as food additives for preventing the oxidative deterioration of food in the food industry [11]. However, nowadays, the application of natural antioxidants is not widely used in the food industry because of their low production and expensive price [12]. Therefore, in order to obtain more natural antioxidants, it is necessary to develop an effective way to extract antioxidants with a strong antioxidant activity from natural products.

Melastoma sanguineum Sims is a genus of shrub in the family Melastomataceae, and widely distributed in China, India, and Malaysia [13]. It is a often used as a garden pot plant due to its attractive purple red flowers. Its fruit are cup shaped and are $1.2-1.6 \mathrm{~cm}$ in length, and the top of fruit is wider than its base. The fruit is covered with red, long, hard, and coarse hair. The pulp is sweet and edible [14]. This fruit is usually consumed by people, and is used to help digestion in folk medicine. In recent years, the biological activities of Melastoma sanguineum Sims have been reported. Ik-Soo et al. found that the extract of aerial parts of Melastoma sanguineum Sims could inhibit the formation of advanced glycation end-products and reduce the activity of aldose reductase, thus illustrating potential for delaying and preventing diabetic complications [15]. In addition, Melastoma sanguineum Sims, together with Embelia laeta and Paeonia ostii, could be used to treat osteomyelitis and inflammation [16]. In our previous study, the fruit of Melastoma sanguineum Sims was found to have an extremely strong antioxidant property, which indicated that the fruit of Melastoma sanguineum Sims could be a rich source of natural antioxidants [17]. In order to fully utilize the fruit of Melastoma sanguineum Sims, developing an efficient method to extract its antioxidants and identify the components of these extracts, is necessary.

At present, the methods used to extract natural antioxidants from natural products include conventional (e.g., maceration, steam distillation, and Soxhlet extraction) and non-conventional (e.g., ultrasound-assisted extraction, microwave-assisted extraction, supercritical fluid extraction, and subcritical water extraction) extraction methods [18,19]. Compared with conventional extraction methods, non-conventional extraction methods are usually time-saving and require less organic solvent $[20,21]$. Therefore, non-conventional extraction methods are becoming more and more popular, especially ultrasound-assisted extraction (UAE). UAE is an effective and environmentally friendly extraction method. Ultrasound possesses a mechanical effect that can promote eddy and internal diffusion, thus increasing the mass transfer and penetration of the solvent into the sample matrix [22]. Cavitation induced by ultrasound can break cell walls, accelerating the release of the contents [23,24]. Furthermore, UAE is simple and inexpensive, and can be applied to industrial production on a large scale [25]. In this study, an UAE method was developed for extracting natural antioxidants from the fruit of Melastoma sanguineum Sims.

Many extraction parameters (e.g., concentration of solvent, solvent/material ratio, temperature, extracting time, and ultrasound power) can significantly affect the extraction efficiency of UAE, and the parameters could also interact with each other [26-29]. Therefore, it is important to optimize these parameters for obtaining high extraction efficiency. Response surface methodology (RSM) is a frequently-used tool for optimizing the extraction parameters [30]. RSM is an effective mathematical and statistical tool which is based on the fit of a polynomial equation to the experimental data, which then makes statistical previsions [31]. It can not only investigate the effect of independent parameters, but also the interaction of several parameters [32]. In the present study, single-factor 
experiments were adopted to investigate the effects of five independent extraction parameters (ethanol concentration, solvent/material ratio, extracting time, temperature, and ultrasound power) on the extraction efficiency of natural antioxidants from the fruit of Melastoma sanguineum Sims, and a RSM with a five-level, three-variable central composite rotatable design (CCRD) was then adopted, in order to study the interaction of three key extraction parameters. In addition, the extraction efficiencies of UAE and two conventional extraction methods (maceration and Soxhlet extraction) were compared. Furthermore, the phenolic compounds in the extract, obtained under the optimal extraction conditions, were identified and quantified by liquid chromatography-tandem mass spectrometry.

\section{Results and Discussion}

\subsection{Single Factor Experiment Analysis}

\subsubsection{Effect of Ethanol Concentration}

Due to the cheap and nontoxic characteristics of ethanol and water, aqueous ethanol is frequently applied to extract natural antioxidants from natural products [30,31]. In this study, the effect of ethanol concentration on extraction efficiency was studied under the following conditions: solvent/material ratio of $10 \mathrm{~mL} / \mathrm{g}$, extracting time of $30 \mathrm{~min}$, temperature at $30^{\circ} \mathrm{C}$, and ultrasound power of $400 \mathrm{~W}$. As shown in Figure 1a, when the ethanol concentration was increased from $10 \%$ to $50 \%(v / v)$, the antioxidant activity gradually increased $(p<0.05)$. When the ethanol concentration reached $50 \%$, the antioxidant activity reached its peak. Following this, with the increase of ethanol concentration, the antioxidant activity gradually decreased $(p<0.05)$. According to the "like dissolves like" theory [33], 50\% ethanol might have the most suitable polarity for antioxidant components in the fruit of Melastoma sanguineum Sims. Thus, in subsequent experiments, $50 \%$ ethanol was used as the extraction solvent.

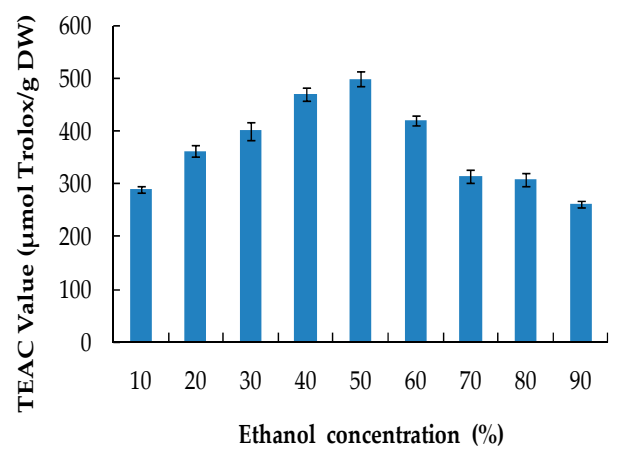

(a)

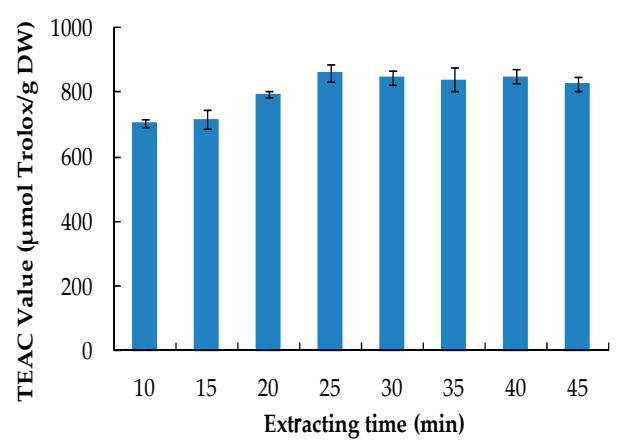

(c)

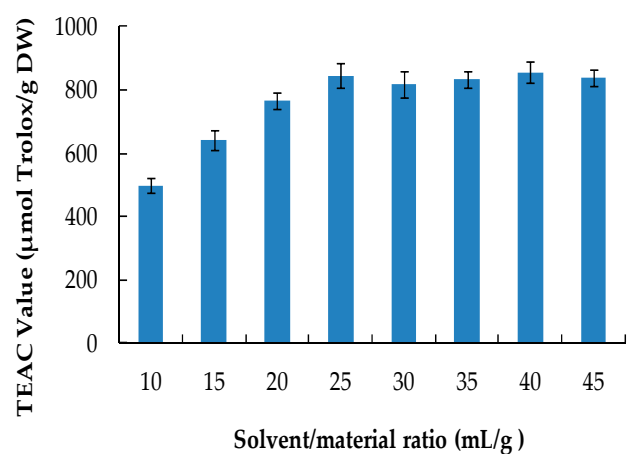

(b)

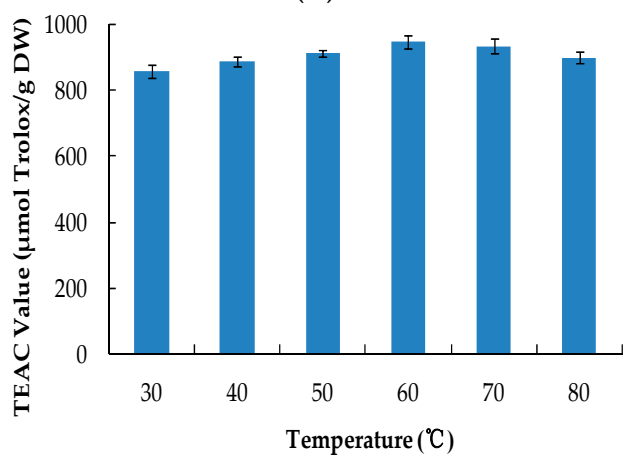

(d)

Figure 1. Cont. 


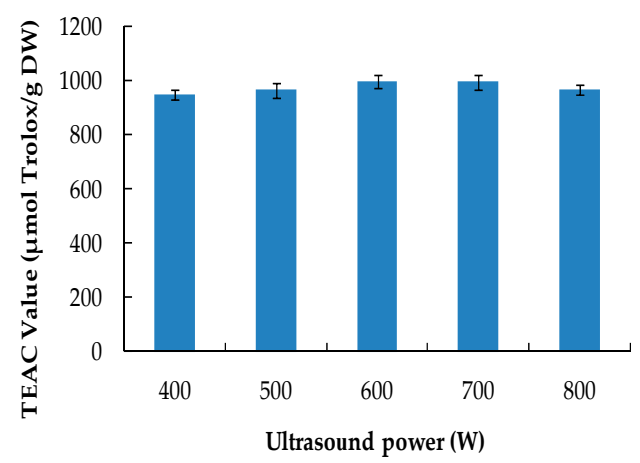

(e)

Figure 1. Effects of ethanol concentration (a); solvent/material ratio (b); extracting time (c); temperature (d) and ultrasound power (e) on the antioxidant activity of the extracts.

\subsubsection{Effect of Solvent/Material Ratio}

The impact of the solvent/material ratio on the extraction efficiency of natural antioxidants from the fruit of Melastoma sanguineum Sims was investigated with 50\% ethanol, $30 \mathrm{~min}$ extraction time, $30{ }^{\circ} \mathrm{C}$ temperature, and $400 \mathrm{~W}$ ultrasound power. The results are showed in Figure $1 \mathrm{~b}$. When the solvent/material ratio increased from $10 \mathrm{~mL} / \mathrm{g}$ to $25 \mathrm{~mL} / \mathrm{g}$, the antioxidant activity gradually increased $(p<0.05)$. When the solvent/material ratio reached $25 \mathrm{~mL} / \mathrm{g}$, the antioxidant activity reached its peak. When the solvent/material ratio increased from $25 \mathrm{~mL} / \mathrm{g}$ to $45 \mathrm{~mL} / \mathrm{g}$, no significant change was observed. Generally, a higher solvent/material ratio results in a greater concentration difference, that can then promote mass transfer and accelerate the dissolution of solute. However, when the dissolution process reaches its equilibrium, further increasing the solvent/material ratio doesn't improve the extraction efficiency [34,35]. Thus, $25 \mathrm{~mL} / \mathrm{g}$ solvent/material ratio was applied in the subsequent experiments.

\subsubsection{Effect of Extracting Time}

The effect of the extracting time on the extraction efficiency of natural antioxidants from the fruit of Melastoma sanguineum Sims was investigated with $50 \%$ ethanol, $25 \mathrm{~mL} / \mathrm{g}$ solvent/material ratio, $30{ }^{\circ} \mathrm{C}$ temperature, and $400 \mathrm{~W}$ ultrasound power. The corresponding results are shown in Figure $1 \mathrm{c}$. When the extracting time increased from $10 \mathrm{~min}$ to $25 \mathrm{~min}$, the antioxidant activity increased $(p<0.05)$. However, no significant difference was observed from $25 \mathrm{~min}$ to $40 \mathrm{~min}$. When the extracting time was prolonged to $45 \mathrm{~min}$, the antioxidant activity slightly decreased $(p>0.05)$. The results show that ultrasound could accelerate the release of antioxidants from the material in a short period of time. However, as the ultrasound time is prolonged, ultrasound might destroy the antioxidants, resulting in the decrease of antioxidant activity [36]. Therefore, $25 \mathrm{~min}$ was chosen for the subsequent experiments.

\subsubsection{Effect of Extracting Temperature}

The effect of the extracting temperature on the extraction efficiency of antioxidants from the fruit of Melastoma sanguineum Sims was studied with $50 \%$ ethanol, $25 \mathrm{~mL} / \mathrm{g}$ solvent/material ratio, $25 \mathrm{~min}$ extracting time, and $400 \mathrm{~W}$ ultrasound power. As shown in Figure 1d, when the extracting temperature increased from $30{ }^{\circ} \mathrm{C}$ to $60^{\circ} \mathrm{C}$, the antioxidant activity increased $(p<0.05)$. As the temperature rose from $60{ }^{\circ} \mathrm{C}$ to $80{ }^{\circ} \mathrm{C}$, the antioxidant activity significantly decreased $(p<0.05)$. The reason for this might be that a higher temperature initially promotes the diffusion, but when the temperature exceeds $60{ }^{\circ} \mathrm{C}$, some heat labile antioxidant components are destroyed [37]. Therefore, $60^{\circ} \mathrm{C}$ was the optimal extracting temperature. 


\subsubsection{Effect of Ultrasound Power}

The effect of ultrasound power on the extraction efficiency of antioxidants from the fruit of Melastoma sanguineum Sims was studied with $50 \%$ ethanol, $25 \mathrm{~mL} / \mathrm{g}$ solvent/material ratio, $25 \mathrm{~min}$ extracting time, and $60{ }^{\circ} \mathrm{C}$ temperature. The corresponding results are shown in the Figure 1e. When the ultrasound power rose from $400 \mathrm{~W}$ to $600 \mathrm{~W}$, the antioxidant activity increased significantly $(p<0.05)$. As the ultrasound power rose from $600 \mathrm{~W}$ to $800 \mathrm{~W}$, the antioxidant activity slightly decreased $(p>0.05)$. The results indicate that the extraction efficiency was improved with the increasing ultrasound power, but when the ultrasound power exceeded $600 \mathrm{~W}$, some antioxidant components were possibly degraded, which was consistent with the other report [38]. It should be pointed out that the ultrasound power was only the energy input to the generator, and that the actual ultrasonic energy introduced in the system was $12.5,16.7,19.6,24.3$, and $27.1 \mathrm{~W} / \mathrm{L}$, in response to the energy inputs of $400,500,600,700$, and $800 \mathrm{~W}$, respectively.

\subsection{Optimization by Response Surface Methodology}

\subsubsection{Experimental Design and Results}

According to the results of the single factor experiment, the effects of ethanol concentration, solvent/material ratio, and extracting time on the extraction efficiency, were more significant than those of the other factors. Therefore, they were further optimized by RSM under the conditions of a $60{ }^{\circ} \mathrm{C}$ extracting temperature and an ultrasound power of $600 \mathrm{~W}$. A three-variable, five-level central composite rotatable design (CCRD) was adopted in RSM, and 50\% ethanol, $25 \mathrm{~mL} / \mathrm{g}$ solvent/material ratio, and 25 min extracting time, were selected as the middle level. The detailed experimental design, actual value, and predicted value, are shown in Table 1 . The results show that the actual antioxidant activity changed from 591.72 to $1067.81 \mu \mathrm{mol}$ Trolox/g DW.

Table 1. The experimental design, actual value, and predicted value, of response surface methodology.

\begin{tabular}{cccccc}
\hline \multirow{2}{*}{ Run } & $\begin{array}{c}\mathbf{X}_{\mathbf{1}} \text { (Ethanol } \\
\text { Concentration, } \%)\end{array}$ & $\begin{array}{c}\mathbf{X}_{\mathbf{2}} \text { (Solvent/Material } \\
\text { Ratio, } \mathbf{m L} / \mathbf{g})\end{array}$ & $\begin{array}{c}\mathbf{X}_{\mathbf{3}} \text { (Extracting } \\
\text { Time, } \mathbf{m i n})\end{array}$ & \multicolumn{2}{c}{$\mathbf{Y}$ (TEAC Value, $\boldsymbol{\mu m o l ~ T r o l o x / g ~ D W ) ~}$} \\
\cline { 5 - 6 } & & 25 & 25 & 988.49 & Actual Value \\
Predicted Value \\
\hline 1 & 50 & 25 & 25 & 981.79 & 998.34 \\
2 & 50 & 35 & 15 & 876.92 & 905.34 \\
3 & 40 & 35 & 35 & 855.01 & 846.94 \\
4 & 60 & 35 & 35 & 1067.81 & 1050.23 \\
5 & 40 & 25 & 25 & 591.72 & 604.16 \\
6 & 66.82 & 25 & 25 & 1005.26 & 998.34 \\
7 & 50 & 25 & 25 & 999.67 & 975.19 \\
8 & 33.18 & 25 & 8.18 & 789.55 & 758.87 \\
9 & 50 & 41.82 & 25 & 911.31 & 921.25 \\
10 & 50 & 25 & 25 & 1045.49 & 998.34 \\
11 & 50 & 15 & 35 & 799.64 & 779.95 \\
12 & 60 & 25 & 41.82 & 997.43 & 1016.08 \\
13 & 50 & 8.18 & 25 & 846.54 & 824.57 \\
14 & 50 & 25 & 25 & 1008.61 & 998.34 \\
15 & 50 & 35 & 15 & 689.15 & 676.78 \\
16 & 60 & 15 & 15 & 593.10 & 619.19 \\
17 & 60 & 25 & 25 & 958.32 & 998.34 \\
18 & 50 & 15 & 35 & 971.98 & 992.86 \\
19 & 40 & 15 & 15 & 840.55 & 857.13 \\
\hline 20 & 40 & 28.29 & 34.29 & 1074.61 & 1077.37 \\
\hline validation & 42.98 & & & & \\
\hline
\end{tabular}

\subsubsection{Fitting the Model}

The results of Table 1 were analyzed using multiple regression fitting, and a quadratic polynomial regression model equation of the TEAC value $(Y)$ to ethanol concentration $\left(X_{1}\right)$, solvent/material ratio $\left(\mathrm{X}_{2}\right)$ and extracting time $\left(\mathrm{X}_{3}\right)$ was obtained. The regression model equation is shown in Equation (1).

$$
Y=998.34-110.31 X_{1}+28.74 X_{2}+76.47 X_{3}+2.4 X_{1} X_{2}+6.26 X_{1} X_{3}+2.35 X_{2} X_{3}-73.77 X_{1}^{2}-44.35 X_{2}^{2}-39.2 X_{3}^{2}
$$


The reliability of this quadratic polynomial model was analyzed by an analysis of variance (ANOVA), and the results of the ANOVA are shown in Table 2. The high $F$ value (40.59) and low $p$ value $(p<0.0001)$ of this model showed that the regression model was reliable. In addition, the low $F$ value (1.32) and high $p$ value (0.385) of "lack of fit", indicated that the "lack of fit" was non-significant, which further confirmed the reliability of this regression model. The determination coefficient $\left(R^{2}\right)$ was 0.973 , and the adjusted determination coefficient (Adj. $R^{2}$ ) was 0.949 , which indicated that the regression model could explain $94.9 \%$ of the response value variations.

Table 2. Analysis of variance (ANOVA) of the response surface model.

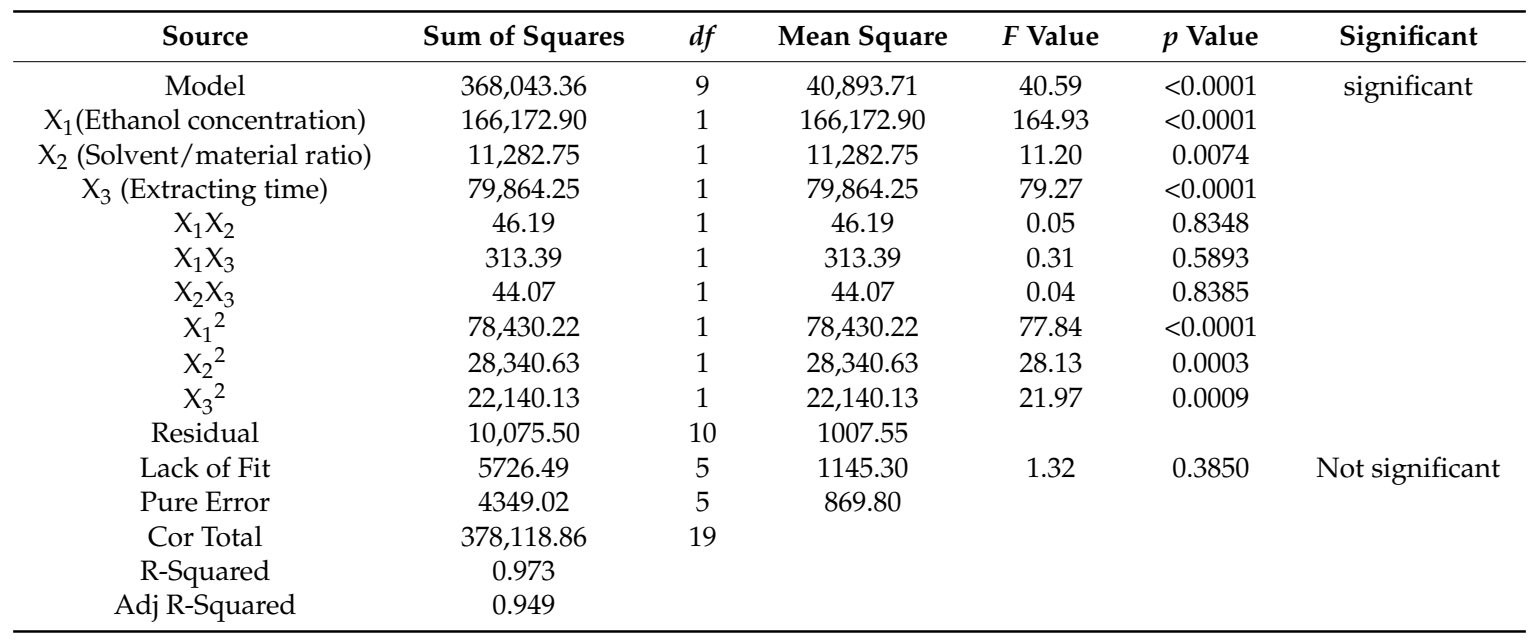

\subsubsection{Response Surfaces Analysis}

According to the results of Table 1, the three dimensional response surface plots were obtained, and are shown in Figure 2. The response surface plots were able to illustrate the relationship between the independent variables and the response value. As shown in Figure 2a, when the extracting time was fixed at $25 \mathrm{~min}$, the response value (TEAC value) increased with decreasing ethanol concentration over a certain range, but when the ethanol concentration was reduced to nearly $40 \%$, the response value was no longer increased. The response value increased with an increasing solvent/material ratio over a certain range, but when the solvent/material ratio was more than about $30 \mathrm{~mL} / \mathrm{g}$, the response value was no longer increased. In Figure $2 b$, when the solvent/material ratio was fixed at $25 \mathrm{~mL} / \mathrm{g}$, the response value increased with increasing extracting time over a certain range, but when the extracting time was increased to nearly $35 \mathrm{~min}$, the response value was no longer increased. In Figure 2c, when the ethanol concentration was fixed at $50 \%$, the effects of the solvent/material ratio and extracting time on the response value were similar to those of Figure 2a,b. According to the three response surface plots, the effects of ethanol concentration, solvent/material ratio, and extracting time on the response value, were not just simple linear effects; there were also quadratic effects. Therefore, each independent variable had an optimal value in the range. Under the condition of the optimal value, the response value had the maximum value. Based on the ANOVA and response surface plots, the ethanol concentration and extracting time had a more significant effect on the response value than the solvent/material ratio. 
Design-Expert?Software

Factor Coding: Actual

TEAC Value

- Design points above predicted value

1067.81

591.721

X1 = A: Ethanol concentration X2 = B: Solvent/material ratio

Actual Factor

C. Time $=25.00$

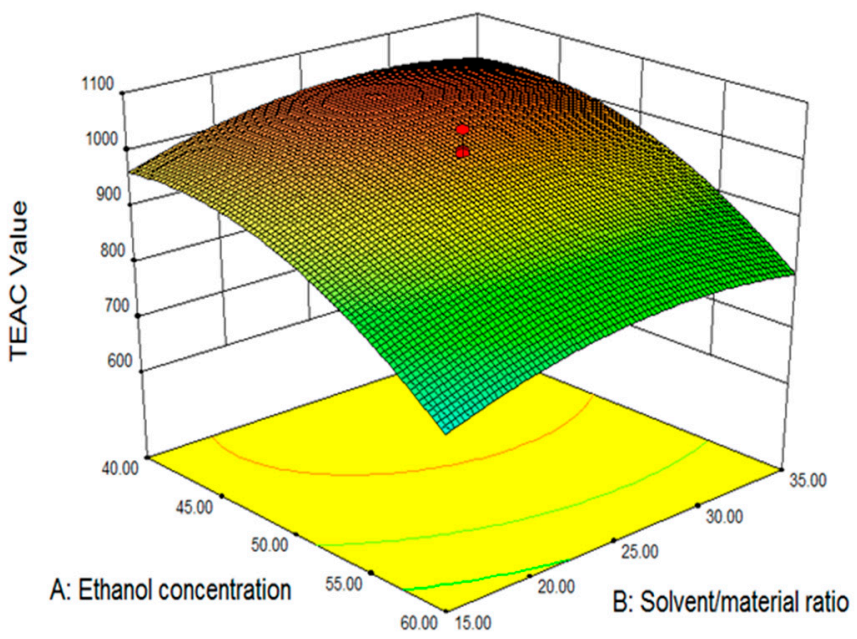

(a)

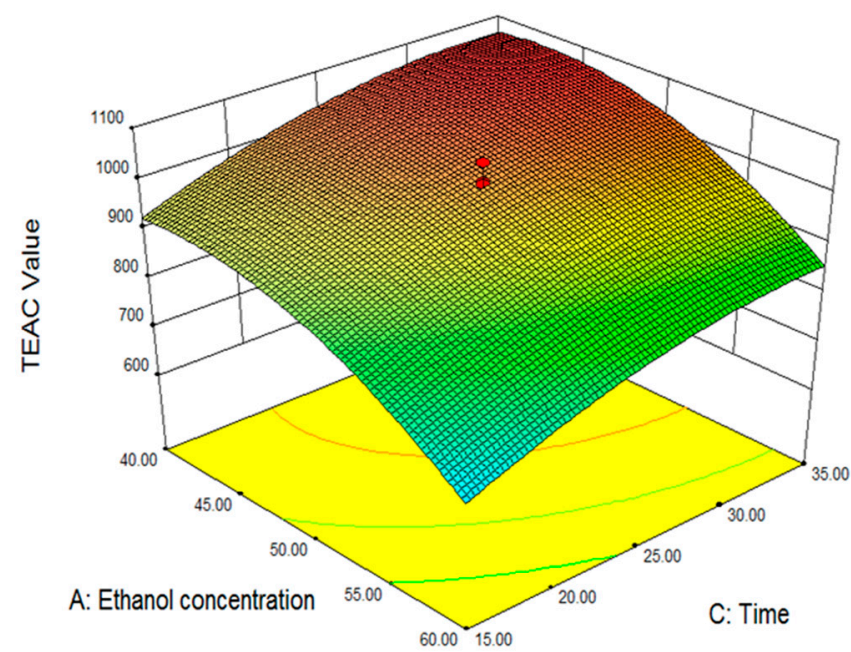

(b)

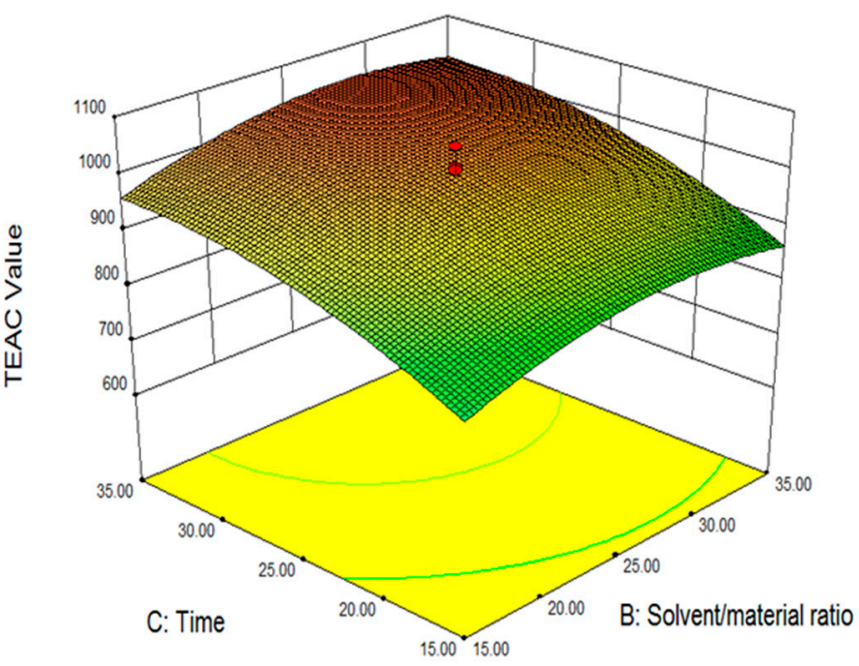

(c)

Figure 2. Response surface plots of the effects of solvent/material ratio $(\mathrm{mL} / \mathrm{g})$ and ethanol concentration (\%) (a); extracting time ( $\mathrm{min}$ ) and ethanol concentration (b); and solvent/material ratio and extracting time (c) on TEAC value ( $\mu \mathrm{mol}$ Trolox/g DW). 


\subsubsection{Validation of Predicted Value}

According to the response model, the optimal extraction conditions were obtained as follows: ethanol concentration of $42.98 \%$, solvent/material ratio of $28.29 \mathrm{~mL} / \mathrm{g}$, extracting time of $34.29 \mathrm{~min}$, temperature of $60{ }^{\circ} \mathrm{C}$, and ultrasound power of $600 \mathrm{~W}$. Under the optimal extraction conditions, the predicted value was $1077.37 \mu \mathrm{mol}$ Trolox/g DW. In order to confirm the accuracy of the response model, a verification experiment with the optimal extraction conditions was performed, and the result showed that the TEAC value was $1074.61 \pm 32.56 \mu$ mol Trolox $/ g$ DW. The result of the verification experiment was in agreement with the predicted value, which indicated that the response model was reliable and accurate. In addition, the TEAC value was $826.27 \pm 9.07 \mu \mathrm{mol}$ Trolox/g DW under the optimized extraction conditions without ultrasound, which indicated that ultrasound played an important role in improving the extraction efficiency.

\subsection{Comparison of UAE with Conventional Extraction Methods}

A comparative study was carried out between UAE and conventional extraction methods (maceration and Soxhlet extraction). The corresponding results are shown in Table 3. Compared with maceration extraction, UAE improved the extraction efficiency by $49 \%$, and saved a lot of time. Compared with Soxhlet extraction, UAE improved the extraction efficiency by 1.07 times, and required a lower temperature and shorter time. The results were consistent with other reports on the extraction of natural antioxidants from black tea, walnut green husk, and the flower of Limonium sinuatum [39-41]. In addition, the total phenolic content (TPC) and total flavonoid content (TFC) of the extract obtained by UAE were significantly higher than those by maceration and Soxhlet extraction. The results indicated that UAE was the most effective method among the three extraction methods. The mechanical effect and cavitation induced by ultrasound disrupt the cell wall and increase mass transfer [42,43], which can explain the high efficiency of UAE.

Table 3. The comparison of UAE with conventional extraction methods.

\begin{tabular}{ccccccc}
\hline $\begin{array}{c}\text { Extracting } \\
\text { Methods }\end{array}$ & $\begin{array}{c}\text { Ethanol } \\
\text { Concentration }\end{array}$ & Time & Temperature & $\begin{array}{c}\text { TEAC Value } \\
\text { ( } \mathbf{m o l} \text { Trolox/g DW) }\end{array}$ & $\begin{array}{c}\text { TPC } \\
(\mathbf{m g} \text { GAE/g DW) }\end{array}$ & $\begin{array}{c}\text { TFC } \\
\text { (mg QE/g DW) }\end{array}$ \\
\hline Maceration & $42.98 \%$ & $24 \mathrm{~h}$ & $25^{\circ} \mathrm{C}$ & $723.27 \pm 11.61$ & $104.21 \pm 2.17$ & $1.39 \pm 0.07$ \\
Soxhlet & $42.98 \%$ & $4 \mathrm{~h}$ & $95^{\circ} \mathrm{C}$ & $518.37 \pm 23.23$ & $76.05 \pm 2.71$ & $1.89 \pm 0.16$ \\
UAE & $42.98 \%$ & $34.29 \mathrm{~min}$ & $60^{\circ} \mathrm{C}$ & $1074.61 \pm 32.56$ & $158.61 \pm 6.44$ & $2.58 \pm 0.18$ \\
\hline
\end{tabular}

\subsection{Identification and Quantification of Phenolic Components}

The identification of phenolic compounds helped to explain the strong antioxidant properties of the extract. So, the characterization of phenolic compounds in the extract obtained under optimal extraction conditions was performed by liquid chromatography-tandem mass spectrometry. Seven phenolic components were identified and quantified in the extract. As shown in Table 4, the highest phenolic component was epicatechin gallate, followed by epicatechin, rutin, epigallocatechin, protocatechuic acid, chlorogenic acid, and quercetin. Compared with other foods, the contents of some phenolic compounds in the Melastoma sanguineum Sims fruit were higher than those in other foods, and the contents of some phenolic compounds in the Melastoma sanguineum Sims fruit were lower than those in other foods [44-46]. For example, the contents of rutin and chlorogenic acid in the Melastoma sanguineum Sims fruit were 2.8 and 2.4 times higher, respectively, than those in whole grain quinoa [47], and the content of epicatechin in the Melastoma sanguineum Sims fruit was eight times higher than that in the Thelephora ganbajun mushroom [48]. However, the content of chlorogenic acid in Turkish coffee was 25 times higher than that in the Melastoma sanguineum Sims fruit [49], the content of epicatechin in Aronia melanocarpa Elliot was 1.7 times higher than that in the Melastoma sanguineum Sims fruit [50], the content of quercetin in mango was 7.8 times than that in the Melastoma sanguineum Sims fruit, and the contents of quercetin and chlorogenic acid in orange was 18.2 and 7.4 times higher, respectively, than that in the Melastoma sanguineum Sims fruit [44]. 
These phenolic components have a strong antioxidant activity [51-53], which might be part of the reason why the Melastoma sanguineum Sims fruit extract had a strong antioxidant capacity. In addition, these phenolic components have been proved to have various other biological activities, such as anti-inflammatory, antibacterial, anticancer, anti-hyperglycemia, hepatoprotective, and cardiovascular protective effects [54-56]. Therefore, the Melastoma sanguineum Sims fruit extract might have potential health benefits.

Table 4. The contents of phenolic components in extract.

\begin{tabular}{ccccc}
\hline $\begin{array}{c}\text { Phenolic } \\
\text { Components }\end{array}$ & $\begin{array}{c}\text { Retention Time } \\
\left(\boldsymbol{t}_{\mathbf{R}}, \mathbf{m i n}\right)\end{array}$ & $\begin{array}{c}\text { Parent Ion } \\
\left(\mathbf{m} / \mathbf{z},[\mathbf{M}-\mathbf{H}]^{-}\right)\end{array}$ & $\begin{array}{c}\text { Product Ion } \\
(\mathbf{m} / \mathbf{z})\end{array}$ & $\begin{array}{c}\text { Contents } \\
(\boldsymbol{\mu g} / \mathbf{g} \mathbf{D W})\end{array}$ \\
\hline epicatechin gallate & 6.87 & 441 & 169 & $1019.57 \pm 99.39$ \\
epicatechin & 5.4 & 289 & 203 & $90.34 \pm 4.84$ \\
rutin & 9.67 & 609 & 300 & $61.6 \pm 1.59$ \\
epigallocatechin & 3.03 & 305 & 137 & $28.67 \pm 2.62$ \\
protocatechuic acid & 3.09 & 152.9 & 107.8 & $3.22 \pm 0.23$ \\
chlorogenic acid & 4.13 & 353 & 191 & $2.34 \pm 0.28$ \\
quercetin & 11.8 & 301 & 179 & $1.39 \pm 0.18$ \\
\hline
\end{tabular}

\section{Materials and Methods}

\subsection{Chemicals and Reagents}

2,2'-azinobis (3-ethylbenothiazoline-6-sulfonic acid) diammonium salt (ABTS), 6-hydroxy-2,5,7,8tetramethylchromane-2-carboxylic acid (Trolox), Folin-Ciocalteu's phenol reagent, gallic acid, and phenolic standards (chlorogenic acid, coffeic acid, daidzein, equol, epicatechin, epigallocatechin, epicatechin gallate, ferulic acid, genistein, glycitein, $p$-coumaric acid, protocatechuic acid, quercetin, rutin, and resveratrol) were purchased from Sigma-Aldrich (St. Louis, MO, USA). Potassium persulphate, aluminum chloride hexahydrate, potassium acetate, and sodium carbonate were purchased from Tianjin Chemical Factory (Tianjin, China). The formic acid and methanol used for chromatographic analysis were chromatographically pure. All other chemicals and reagents were analytically pure.

\subsection{Sample Preparation}

The mature fruits of Melastoma sanguineum Sims were manually harvested from many trees in the Lung Fu Mountain, Hong Kong, China, in October 2016. After picking, they were stored in a refrigerator at $4{ }^{\circ} \mathrm{C}$, and used within one month. The fruits were cleaned using deionized water, and air dried in the room of a laboratory at room temperature, for about $4 \mathrm{~h}$. The fruits were ground into fine particles by a special grinder with stainless steel knife (model JYL-C022E, Joyoung Co., Ltd., Jinan, Shandong, China), and stored in the dark at $4{ }^{\circ} \mathrm{C}$.

\subsection{Extraction of Natural Antioxidants}

\subsubsection{Ultrasound-Assisted Extraction}

The powder of Melastoma sanguineum Sims fruits $(0.2 \mathrm{~g})$ was put into a tube with an appropriate volume of ethanol aqueous solution. Then, the tube containing the mixture was placed into the water bath of an ultrasound device (Kj1012B; Kejin Ultrasonic Instrument Factory, Guangzhou, China), and was sonicated at a preset extraction time, temperature, and power. The ultrasonic energy introduced in the system was measured and calculated according to the literature [39,57], and was 12.5, $16.7,19.6,24.3$, and $27.1 \mathrm{~W} / \mathrm{L}$, in response to the energy inputs to the generator of 400, 500, 600, 700, and $800 \mathrm{~W}$, respectively. After sonication, the sample was centrifuged at $4200 \times g$ for $30 \mathrm{~min}$, and the supernatant was collected for subsequent determination of antioxidant activity by spectrophotometry. 
In addition, the supernatant was filtered using a $0.45 \mu \mathrm{m}$ membrane for the determination of phenolic compounds by liquid chromatography-tandem mass spectrometry.

\subsubsection{Maceration Extraction}

The powder of the Melastoma sanguineum Sims fruits $(0.2 \mathrm{~g})$ was mixed with $5.658 \mathrm{~mL}$ of $42.98 \%$ ethanol, and extracted at $25{ }^{\circ} \mathrm{C}$ for $24 \mathrm{~h}$ in a shaking water bath. Then, the extraction solution was centrifuged at $4200 \times g$ for $30 \mathrm{~min}$, and the supernatant was collected for subsequent determination.

\subsubsection{Soxhlet Extraction}

The Soxhlet extraction process was carried out according to the method reported by $\mathrm{Xu}$ et al., with slight modifications [48]. The powder of the Melastoma sanguineum Sims fruits (1.0 g) was enveloped with Whatman filter paper, which was placed in a Soxhlet extractor. Then, $200 \mathrm{~mL}$ of $42.98 \%$ ethanol was used as the solvent, and heated at $95{ }^{\circ} \mathrm{C}$. After $4 \mathrm{~h}$ of extraction in the Soxhlet extractor, the extraction solution was collected for subsequent determination.

\subsection{Experimental Design}

\subsubsection{Single Factor Experiment}

The five factors (ethanol concentration, solvent/material ratio, extracting time, ultrasound temperature, and ultrasound power) were chosen to carry out a single factor experiment. The level gradients of each factor were: ethanol concentration $10 \%, 20 \%, 30 \%, 40 \%, 50 \%, 60 \%, 70 \%, 80 \%, 90 \%$; solvent/material ratio 10, 15, 20, 25, 30, 35, 40, $45 \mathrm{~mL} / \mathrm{g}$; extracting time 10, 15, 20, 25, 30, 35, 40, $45 \mathrm{~min}$; ultrasound temperature $30,40,50,60,70,80^{\circ} \mathrm{C}$; ultrasound power $400,500,600,700,800 \mathrm{~W}$.

\subsubsection{Response Surface Methodology}

According to the results of the single factor experiment, three main factors (ethanol concentration, solvent/material ratio, and extracting time) were selected for RSM design. A three-factor, five-level CCRD, with 20 experimental runs was carried out. The independent variables and their five levels are presented in Table 5. The results of CCRD were analyzed using ANOVA, and fitted to a second-order polynomial equation, as follows:

$$
Y=\beta_{0}+\sum \beta_{\mathrm{i}} X_{i}+\sum \beta_{\mathrm{ii}} X_{\mathrm{i}}^{2}+\sum \beta_{\mathrm{ij}} X_{\mathrm{i}} X_{\mathrm{j}}
$$

Table 5. Independent variables and their five levels used for central composite rotatable design.

\begin{tabular}{cccccccc}
\hline \multirow{2}{*}{ Independent Variable } & \multirow{2}{*}{ Units } & \multirow{2}{*}{ Symbol } & \multicolumn{5}{c}{ Coded Levels } \\
\cline { 4 - 8 } & & & $\mathbf{- 1 . 6 8}$ & $\mathbf{- 1}$ & $\mathbf{0}$ & $\mathbf{1}$ & $\mathbf{1 . 6 8}$ \\
\hline Ethanol concentration & $\%(v / v)$ & $\mathrm{X}_{1}$ & 33.18 & 40 & 50 & 60 & 66.82 \\
Solvent/material ratio & $\mathrm{mL} / \mathrm{g}$ & $\mathrm{X}_{2}$ & 8.18 & 15 & 25 & 35 & 41.82 \\
Extracting time & $\mathrm{min}$ & $\mathrm{X}_{3}$ & 8.18 & 15 & 25 & 35 & 41.82 \\
\hline
\end{tabular}

In the equation, $Y$ is the response value, $X_{i}$ and $X_{j}$ are the independent variables, $\beta_{0}$ is the intercept, and $\beta_{\mathrm{i}}, \beta_{\mathrm{ij}}$, and $\beta_{\mathrm{ii}}$ are the regression coefficients for the linear, interaction, and quadratic terms, respectively.

The multiple regression fitting of the experimental data and the ANOVA of the quadratic polynomial regression model were performed using Design Expert version 8.06.1 software (Stat-Ease, Minneapolis, MN, USA). 


\subsection{Determination of Antioxidant Capacity}

Many methods have been developed to evaluate the antioxidant activity of foods and plants, and different methods could lead to a wide variation of antioxidant capacities [58]. However, the antioxidant capacities obtained using different methods usually have a very high correlationship $[17,45]$. Thus, the optimal extraction parameters obtained using different monitoring methods of antioxidant activity are usually the same or similar [59]. In the literature, a Trolox equivalent antioxidant capacity (TEAC) assay was usually selected for evaluating the antioxidant capacity of the extract, because it is a simple and rapid method, and can measure the antioxidant capacities of hydrophilic and lipophilic compounds in the same sample [17]. The TEAC assay was carried out based on the method previously established [60]. In brief, the ABTS ${ }^{\bullet+}$ stock solution was prepared by mixing $2.45 \mathrm{mmol} / \mathrm{L}$ potassium persulfate solution and $7 \mathrm{mmol} / \mathrm{L} \mathrm{ABTS}^{\bullet+}$ solution with a ratio of 1:1 (v/v), and was then placed in the dark for $16 \mathrm{~h}$ and used within two days. The ABTS ${ }^{\bullet+}$ working solution was obtained by diluting $\mathrm{ABTS}^{\bullet+}$ stock solution, and the absorbance of $\mathrm{ABTS}^{\bullet+}$ working solution was $0.70 \pm 0.05$ at $\lambda_{734 \mathrm{~nm}}$. The $0.1 \mathrm{~mL}$ diluted sample was added to the $3.8 \mathrm{~mL} \mathrm{ABTS}^{\bullet+}$ working solution, and then incubated at room temperature for $6 \mathrm{~min}$. After incubation, the absorbance of mixture was measured at $\lambda_{734 \mathrm{~nm}}$, immediately. Trolox was employed as a reference standard, and the results were expressed as $\mu \mathrm{mol}$ Trolox/g DW of fruit.

\subsection{Determination of Total Phenolic Content}

The total phenolic content was determined on the basis of the method previously established [61]. In brief, a $0.50 \mathrm{~mL}$ diluted sample was added to $2.5 \mathrm{~mL}$ of $0.2 \mathrm{~mol} / \mathrm{L}$ diluted Folin-Ciocalteu reagent. After $4 \mathrm{~min}$ of incubation, $2 \mathrm{~mL}$ saturated sodium carbonate solution was added. The absorbance of mixture was measured at $\lambda_{760 \mathrm{~nm}}$ after $2 \mathrm{~h}$ of incubation at room temperature. Gallic acid was employed as a reference standard, and the results were expressed as mg of gallic acid equivalent (mg GAE)/g DW of fruit.

\subsection{Determination of Total Flavonoid Content}

The total flavonoid content was determined on the basis of the literature reported by Kalia et al. [62]. In brief, a $0.50 \mathrm{~mL}$ test sample was mixed with $1.5 \mathrm{~mL}$ of $95 \%$ ethanol $(v / v)$, $0.1 \mathrm{~mL} \mathrm{AlCl}_{3}$ solution $(10 \%, w / v), 0.1 \mathrm{~mL}$ of $1 \mathrm{~mol} / \mathrm{L}$ potassium acetate solution, and $2.8 \mathrm{~mL}$ double distilled water. The absorbance of mixture was determined at $\lambda_{415 \mathrm{~nm}}$ after incubation at room temperature for $30 \mathrm{~min}$. Quercetin was employed as the reference standard, and the results were expressed as mg quercetin equivalent (mg QE)/g DW of fruit.

\subsection{Identification and Quantification of Phenolic Compounds}

Under optimal extraction conditions, the extract of the Melastoma sanguineum Sims fruit was obtained. The identification and quantification of phenolic compounds in the extract was performed by AB Sciex 4000 Qtrap liquid chromatography-tandem mass spectrometry (SCIEX, Framingham, MA, USA). The separation was performed by Acquity UPLC ${ }^{\circledR}$ HSS T3 column $\left(2.1 \times 100 \mathrm{~mm}, 1.8 \mu \mathrm{m}\right.$, Waters, Milford, MA, USA) at $40{ }^{\circ} \mathrm{C}$. The mobile phase was composed of solution A ( $0.1 \%$ formic acid-water solution) and solution B (methanol), and the flow rate was $0.3 \mathrm{~mL} / \mathrm{min}$. The gradient elution was performed as follows: $15 \% \mathrm{~B}$ at $0-2 \mathrm{~min}, 15 \%-30 \% \mathrm{~B}$ at $2-8 \mathrm{~min}$, $30 \%-80 \%$ B at $8-15 \mathrm{~min}, 80 \% \mathrm{~B}$ at $15-17.5 \mathrm{~min}$, and $15 \% \mathrm{~B}$ at $17.5-19.5 \mathrm{~min}$. The injection volume of the sample was $2 \mu \mathrm{L}$. The conditions of mass spectrometry were as follows: Ion source, ESI source with negative mode; Ion source temperature, $550{ }^{\circ} \mathrm{C}$; detection mode, multiple reaction monitoring (MRM) mode; capillary voltage, $-4500 \mathrm{~V}$; curtain gas, 10 psig; nebulizer gas, 20 psig; auxiliary gas, 20 psig. Seven phenolic components were tentatively identified by tandem mass spectrometry. Then, they were verified by corresponding standard compounds, and quantified by peak areas. 


\subsection{Statistical Analysis}

All of the experiments were carried out in triplicate, and the mean value \pm standard deviation was reported. Statistical analysis was carried out using Design Expert 8.06.1 (Stat-Ease, Minneapolis, MN, USA) and SPSS 20.0 (IBM, Armonk, NY, USA).

\section{Conclusions}

An UAE method has been developed for extracting natural antioxidants from the fruit of Melastoma sanguineum Sims, and RSM was employed for optimizing the extraction parameters. The high Adj. $R^{2}(0.949)$ and consistency between the predicted value and experimental value indicated that the response model was reliable and accurate. The optimal extraction conditions were as follows: ethanol concentration of $42.98 \%$, solvent/material ratio of $28.29 \mathrm{~mL} / \mathrm{g}$, extracting time of $34.29 \mathrm{~min}$, temperature of $60{ }^{\circ} \mathrm{C}$, and ultrasound power of $600 \mathrm{~W}$. Under the optimal extraction conditions, the antioxidant capacity, TPC, and TFC of the extract were $1074.61 \pm 32.56 \mu \mathrm{mol}$ Trolox/g DW, $158.61 \pm 6.44 \mathrm{mg} \mathrm{GAE} / \mathrm{g} \mathrm{DW}$, and $2.58 \pm 0.18 \mathrm{mg} \mathrm{QE} / \mathrm{g} \mathrm{DW}$, respectively. Compared with conventional extraction methods, UAE was proved to be a more effective method for extracting natural antioxidants from the fruit of Melastoma sanguineum Sims. In addition, epicatechin gallate, epicatechin, rutin, epigallocatechin, protocatechuic acid, chlorogenic acid, and quercetin were identified and quantified in the extract, which might contribute to the strong antioxidant capacity of this fruit.

Acknowledgments: This work was supported by the National Natural Science Foundation of China (No. 81372976), Key Project of Guangdong Provincial Science and Technology Program (No. 2014B020205002), and the Hundred-Talents Scheme of Sun Yat-Sen University.

Author Contributions: Tong Zhou and Hua-Bin Li conceived and designed the experiments; Tong Zhou, Dong-Ping $\mathrm{Xu}$, Sheng-Jun Lin, $\mathrm{Ya} \mathrm{Li}$, Jie Zheng, Yue Zhou and Jiao-Jiao Zhang performed the experiments; Tong Zhou analyzed the data and wrote the paper; Hua-Bin Li revised the paper.

Conflicts of Interest: The authors declare no conflict of interest.

\section{References}

1. Lue, J.M.; Lin, P.H.; Yao, Q.Z.; Chen, C.Y. Chemical and molecular mechanisms of antioxidants: Experimental approaches and model systems. J. Cell. Mol. Med. 2010, 14, 840-860. [CrossRef] [PubMed]

2. Lobo, V.; Patil, A.; Phatak, A.; Chandra, N. Free radicals, antioxidants and functional foods: Impact on human health. Pharmacogn. Rev. 2010, 4, 118-126. [CrossRef] [PubMed]

3. Azizova, O.A. Role of free radical processes in the development of atherosclerosis. Biol. Membr. 2002, 19, 451-471.

4. Santilli, F.; D'Ardes, D.; Davi, G. Oxidative stress in chronic vascular disease: From prediction to prevention. Vasc. Pharmacol. 2015, 74, 23-37. [CrossRef] [PubMed]

5. Valko, M.; Leibfritz, D.; Moncol, J.; Cronin, M.T.D.; Mazur, M.; Telser, J. Free radicals and antioxidants in normal physiological functions and human disease. Int. J. Biochem. Cell Biol. 2007, 39, 44-84. [CrossRef] [PubMed]

6. Nicklett, E.J.; Semba, R.D.; Xue, Q.L.; Tian, J.; Sun, K.; Cappola, A.R.; Simonsick, E.M.; Ferrucci, L.; Fried, L.P. Fruit and vegetable intake, physical activity, and mortality in older community-dwelling women. J. Am. Geriatr. Soc. 2012, 60, 862-868. [CrossRef] [PubMed]

7. Boeing, H.; Bechthold, A.; Bub, A.; Ellinger, S.; Haller, D.; Kroke, A.; Leschik-Bonnet, E.; Muller, M.J.; Oberritter, H.; Schulze, M.; et al. Critical review: Vegetables and fruit in the prevention of chronic diseases. Eur. J. Nutr. 2012, 51, 637-663. [CrossRef] [PubMed]

8. Li, A.N.; Li, S.; Zhang, Y.J.; Xu, X.R.; Chen, Y.M.; Li, H.B. Resources and biological activities of natural polyphenols. Nutrients 2014, 6, 6020-6047. [CrossRef] [PubMed]

9. Zhang, Y.J.; Gan, R.Y.; Li, S.; Zhou, Y.; Li, A.N.; Xu, D.P.; Li, H.B. Antioxidant phytochemicals for the prevention and treatment of chronic diseases. Molecules 2015, 20, 21138-21156. [CrossRef] [PubMed] 
10. Guo, Y.J.; Deng, G.F.; Xu, X.R.; Wu, S.; Li, S.; Xia, E.Q.; Li, F.; Chen, F.; Ling, W.H.; Li, H.B. Antioxidant capacities, phenolic compounds and polysaccharide contents of 49 edible macro-fungi. Food Funct. 2012, 3, 1195-1205. [CrossRef] [PubMed]

11. Moure, A.; Cruz, J.M.; Franco, D.; Dominguez, J.M.; Sineiro, J.; Dominguez, H.; Nunez, M.J.; Parajo, J.C. Natural antioxidants from residual sources. Food Chem. 2001, 72, 145-171. [CrossRef]

12. Song, F.L.; Gan, R.Y.; Zhang, Y.; Xiao, Q.; Kuang, L.; Li, H.B. Total phenolic contents and antioxidant capacities of selected Chinese medicinal plants. Int. J. Mol. Sci. 2010, 11, 2362-2372. [CrossRef] [PubMed]

13. Liu, T.; Chen, Y.Y.; Chao, L.F.; Wang, S.Q.; Wu, W.; Dai, S.P.; Wang, F.; Fan, Q.; Zhou, R.C. Extensive hybridization and introgression between Melastoma candidum and M-sanguineum. PLoS ONE 2014, 9, e96680. [CrossRef] [PubMed]

14. Chen, J. Melastomataceae. In Flora Reipublicae Popularis Sinicae; Chen, C., Chang, H., Miau, R., Hsu, T., Eds.; Science Press: Beijing, China, 1984; Volume 53, pp. 152-162.

15. Lee, I.; Kim, I.S.; Lee, Y.M.; Lee, Y.; Kim, J.; Kim, J.S. 2",4"-o-diacetylquercitrin, a novel advanced glycation end-product formation and aldose reductase inhibitor from Melastoma sanguineum. Chem. Pharm. Bull. 2013, 61, 662-665. [CrossRef] [PubMed]

16. Xie, F. Chinese Medicine Useful for Treating Osteomyelitis and Inflammation, Comprises Embelia laeta, Melastoma sanguineum and Paeonia ostii. CN101919897-A; CN101919897-B. 22 December 2010.

17. Fu, L.; Xu, B.T.; Xu, X.R.; Qin, X.S.; Gan, R.Y.; Li, H.B. Antioxidant capacities and total phenolic contents of 56 wild fruits from south china. Molecules 2010, 15, 8602-8617. [CrossRef] [PubMed]

18. Chandrapala, J.; Oliver, C.M.; Kentish, S.; Ashokkumar, M. Use of power ultrasound to improve extraction and modify phase transitions in food processing. Food Rev. Int. 2013, 29, 67-91. [CrossRef]

19. Chemat, F.; Zill-e-Huma; Khan, M.K. Applications of ultrasound in food technology: Processing, preservation and extraction. Ultrason. Sonochem. 2011, 18, 813-835. [CrossRef] [PubMed]

20. Oroian, M.; Escriche, I. Antioxidants: Characterization, natural sources, extraction and analysis. Food Res. Int. 2015, 74, 10-36. [CrossRef]

21. Dai, J.; Mumper, R.J. Plant phenolics: Extraction, analysis and their antioxidant and anticancer properties. Molecules 2010, 15, 7313-7352. [CrossRef] [PubMed]

22. Ji, J.B.; Lu, X.H.; Cai, M.Q.; Xu, Z.C. Improvement of leaching process of geniposide with ultrasound. Ultrason. Sonochem. 2006, 13, 455-462. [CrossRef] [PubMed]

23. Xia, E.-Q.; Ai, X.-X.; Zang, S.-Y.; Guan, T.-T.; Xu, X.-R.; Li, H.-B. Ultrasound-assisted extraction of phillyrin from Forsythia suspensa. Ultrason. Sonochem. 2011, 18, 549-552. [CrossRef] [PubMed]

24. Soria, A.C.; Villamiel, M. Effect of ultrasound on the technological properties and bioactivity of food: A review. Trends Food Sci. Technol. 2010, 21, 323-331. [CrossRef]

25. Pico, Y. Ultrasound-assisted extraction for food and environmental samples. TrAC Trend Anal. Chem. 2013, 43, 84-99. [CrossRef]

26. Gan, C.Y.; Latiff, A.A. Optimization of the solvent extraction of bioactive compounds from Parkia speciosa pod using response surface methodology. Food Chem. 2011, 124, 1277-1283. [CrossRef]

27. Esclapez, M.D.; Garcia-Perez, J.V.; Mulet, A.; Carcel, J.A. Ultrasound-assisted extraction of natural products. Food Eng. Rev. 2011, 3, 108-120. [CrossRef]

28. Carciochi, R.A.; Manrique, G.D.; Dimitrov, K. Optimization of antioxidant phenolic compounds extraction from quinoa (Chenopodium quinoa) seeds. J. Food Sci. Technol. 2015, 52, 4396-4404. [CrossRef] [PubMed]

29. D'Alessandro, L.G.; Dimitrov, K.; Vauchel, P.; Nikov, I. Kinetics of ultrasound assisted extraction of anthocyanins from Aronia melanocarpa (black chokeberry) wastes. Chem. Eng. Res. Des. 2014, 92, 1818-1826. [CrossRef]

30. Saikia, S.; Mahnot, N.K.; Mahanta, C.L. Optimization of phenolic extraction from Averrhoa carambola pomace by response surface methodology and its microencapsulation by spray and freeze drying. Food Chem. 2015, 171, 144-152. [CrossRef] [PubMed]

31. Bezerra, M.A.; Santelli, R.E.; Oliveira, E.P.; Villar, L.S.; Escaleira, L.A. Response surface methodology (RSM) as a tool for optimization in analytical chemistry. Talanta 2008, 76, 965-977. [CrossRef] [PubMed]

32. Belwal, T.; Dhyani, P.; Bhatt, I.D.; Rawal, R.S.; Pande, V. Optimization extraction conditions for improving phenolic content and antioxidant activity in Berberis asiatica fruits using response surface methodology (RSM). Food Chem. 2016, 207, 115-124. [CrossRef] [PubMed] 
33. Ozdemir, C.; Guener, A. Solubility profiles of poly(ethylene glycol)/solvent systems, I: Qualitative comparison of solubility parameter approaches. Eur. Polym. J. 2007, 43, 3068-3093. [CrossRef]

34. Xu, Y.; Pan, S.Y. Effects of various factors of ultrasonic treatment on the extraction yield of all-trans-lycopene from red grapefruit (Citrus paradise Macf.). Ultrason. Sonochem. 2013, 20, 1026-1032. [CrossRef] [PubMed]

35. Ying, Z.; Han, X.; Li, J. Ultrasound-assisted extraction of polysaccharides from mulberry leaves. Food Chem. 2011, 127, 1273-1279. [CrossRef] [PubMed]

36. Xu, D.P.; Zhou, Y.; Zheng, J.; Li, S.; Li, A.N.; Li, H.B. Optimization of ultrasound-assisted extraction of natural antioxidants from the flower of Jatropha integerrima by response surface methodology. Molecules 2016, 21, 18. [CrossRef] [PubMed]

37. Galanakis, C.M.; Tornberg, E.; Gekas, V. Clarification of high-added value products from olive mill wastewater. J. Food Eng. 2010, 99, 190-197. [CrossRef]

38. Yue, T.L.; Shao, D.Y.; Yuan, Y.H.; Wang, Z.L.; Qiang, C.Y. Ultrasound-assisted extraction, HPLC analysis, and antioxidant activity of polyphenols from unripe apple. J. Sep. Sci. 2012, 35, 2138-2145. [CrossRef] [PubMed]

39. Both, S.; Chemat, F.; Strube, J. Extraction of polyphenols from black tea-Conventional and ultrasound assisted extraction. Ultrason. Sonochem. 2014, 21, 1030-1034. [CrossRef] [PubMed]

40. Tabaraki, R.; Rastgoo, S. Comparison between conventional and ultrasound-assisted extractions of natural antioxidants from walnut green husk. Korean J. Chem. Eng. 2014, 31, 676-683. [CrossRef]

41. Xu, D.P.; Zheng, J.; Zhou, Y.; Li, Y.; Li, S.; Li, H.B. Ultrasound-assisted extraction of natural antioxidants from the flower of Limonium sinuatum: Optimization and comparison with conventional methods. Food Chem. 2017, 217, 552-559. [CrossRef] [PubMed]

42. Ma, Y.Q.; Ye, X.Q.; Fang, Z.X.; Chen, J.C.; Xu, G.H.; Liu, D.H. Phenolic compounds and antioxidant activity of extracts from ultrasonic treatment of satsuma mandarin (Citrus unshiu Marc.) peels. J. Agric. Food Chem. 2008, 56, 5682-5690. [CrossRef] [PubMed]

43. Wang, J.; Sun, B.G.; Cao, Y.P.; Tian, Y.A.; Li, X.H. Optimization of ultrasound-assisted extraction of phenolic compounds from wheat bran. Food Chem. 2008, 106, 804-810. [CrossRef]

44. Fu, L.; Xu, B.T.; Xu, X.R.; Gan, R.Y.; Zhang, Y.; Xia, E.Q.; Li, H.B. Antioxidant capacities and total phenolic contents of 62 fruits. Food Chem. 2011, 129, 345-350. [CrossRef]

45. Deng, G.F.; Lin, X.; Xu, X.R.; Gao, L.L.; Xie, J.F.; Li, H.B. Antioxidant capacities and total phenolic contents of 56 vegetables. J. Funct. Food. 2013, 5, 260-266. [CrossRef]

46. Sakakibara, H.; Honda, Y.; Nakagawa, S.; Ashida, H.; Kanazawa, K. Simultaneous determination of all polyphenols in vegetables, fruits, and teas. J. Agric. Food Chem. 2003, 51, 571-581. [CrossRef] [PubMed]

47. Hemalatha, P.; Bomzan, D.P.; Rao, B.V.S.; Sreerama, Y.N. Distribution of phenolic antioxidants in whole and milled fractions of quinoa and their inhibitory effects on alpha-amylase and alpha-glucosidase activities. Food Chem. 2016, 199, 330-338. [CrossRef] [PubMed]

48. Xu, D.P.; Zheng, J.; Zhou, Y.; Li, Y.; Li, S.; Li, H.B. Extraction of natural antioxidants from the Thelephora ganbajun mushroom by an ultrasound-assisted extraction technique and evaluation of antiproliferative activity of the extract against human cancer cells. Int. J. Mol. Sci. 2016, 17, 1664. [CrossRef] [PubMed]

49. Samanidou, V.; Tsagiannidis, A.; Sarakatsianos, I. Simultaneous determination of polyphenols and major purine alkaloids in greek sideritis species, herbal extracts, green tea, black tea, and coffee by high-performance liquid chromatography-diode array detection. J. Sep. Sci. 2012, 35, 608-615. [CrossRef] [PubMed]

50. Oszmianski, J.; Wojdylo, A. Aronia melanocarpa phenolics and their antioxidant activity. Eur. Food Res. Technol. 2005, 221, 809-813. [CrossRef]

51. Pan, M.H.; Chiou, Y.S.; Wang, Y.J.; Ho, C.T.; Lin, J.K. Multistage carcinogenesis process as molecular targets in cancer chemoprevention by epicatechin-3-gallate. Food Funct. 2011, 2, 101-110. [CrossRef] [PubMed]

52. Khan, A.K.; Rashid, R.; Fatima, N.; Mahmood, S.; Mir, S.; Khan, S.; Jabeen, N.; Murtaza, G. Pharmacological activities of protocatechuic acid. Acta Pol. Pharm. 2015, 72, 643-650. [PubMed]

53. Upadhyay, R.; Rao, L.J.M. An outlook on chlorogenic acids-occurrence, chemistry, technology, and biological activities. Crit. Rev. Food Sci. Nutr. 2013, 53, 968-984. [CrossRef] [PubMed] 
54. Mandel, S.A.; Amit, T.; Kalfon, L.; Reznichenko, L.; Weinreb, O.; Youdim, M.B.H. Cell signaling pathways and iron chelation in the neurorestorative activity of green tea polyphenols: Special reference to epigallocatechin gallate (EGCG). J. Alzheimers Dis. 2008, 15, 211-222.

55. Shay, J.; Elbaz, H.A.; Lee, I.; Zielske, S.P.; Malek, M.H.; Huttemann, M. Molecular mechanisms and therapeutic effects of (-)-epicatechin and other polyphenols in cancer, inflammation, diabetes, and neurodegeneration. Oxid. Med. Cell. Longev. 2015, 2015, 181260. [CrossRef] [PubMed]

56. Hosseinzadeh, H.; Nassiri-Asl, M. Review of the protective effects of rutin on the metabolic function as an important dietary flavonoid. J. Endocrinol. Investig. 2014, 37, 783-788. [CrossRef] [PubMed]

57. Li, Y.; Chen, Y.L.; Li, H. Recovery and purification of cholesterol from cholesterol-beta-cyclodextrin inclusion complex using ultrasound-assisted extraction. Ultrason. Sonochem. 2017, 34, 281-288. [CrossRef] [PubMed]

58. Xu, D.P.; Li, Y.; Meng, X.; Zhou, T.; Zhou, Y.; Zheng, J.; Zhang, J.J.; Li, H.B. Natural antioxidants in foods and medicinal plants: Extraction, assessment and resources. Int. J. Mol. Sci. 2017, 18, 96. [CrossRef] [PubMed]

59. Deng, G.F.; Xu, D.P.; Li, S.; Li, H.B. Optimization of ultrasound-assisted extraction of natural antioxidants from sugar apple (Annona squamosa L.) peel using response surface methodology. Molecules 2015, 20, 20448-20459. [CrossRef] [PubMed]

60. Re, R.; Pellegrini, N.; Proteggente, A.; Pannala, A.; Yang, M.; Rice-Evans, C. Antioxidant activity applying an improved ABTS radical cation decolorization assay. Free Radic. Biol. Med. 1999, 26, 1231-1237. [CrossRef]

61. Singleton, V.L.; Rossi, J.A. Colorimetry of total phenolics with phosphomolybdic-phosphotungstic acid reagents. Am. J. Enol. Vitic. 1965, 16, 144-158.

62. Kalia, K.; Sharma, K.; Singh, H.P.; Singh, B. Effects of extraction methods on phenolic contents and antioxidant activity in aerial parts of Potentilla atrosanguinea lodd and quantification of its phenolic constituents by RP-HPLC. J. Agric. Food Chem. 2008, 56, 10129-10134. [CrossRef] [PubMed]

Sample Availability: Samples of the compounds are not available from the authors.

(C) 2017 by the authors; licensee MDPI, Basel, Switzerland. This article is an open access article distributed under the terms and conditions of the Creative Commons Attribution (CC BY) license (http:/ / creativecommons.org/licenses/by/4.0/). 